\title{
Weed Management in White Bean With Pre-plant Incorporated Herbicides
}

\author{
Nader Soltani ${ }^{1}$, Christy Shropshire ${ }^{1}$ \& Peter H. Sikkema ${ }^{1}$ \\ ${ }^{1}$ Department of Plant Agriculture, University of Guelph, Ridgetown, ON, Canada \\ Correspondence: Nader Soltani, Department of Plant Agriculture, University of Guelph, 120 Main St. East, \\ Ridgetown, ON, N0P 2C0, Canada. E-mail: soltanin@uoguelph.ca
}

Received: July 5, 2021

doi:10.5539/jas.v13n10p1
Accepted: August 17, $2021 \quad$ Online Published: September 15, 2021

URL: https://doi.org/10.5539/jas.v13n10p1

\begin{abstract}
Five field experiments were conducted in Ontario Canada during 2018-2020 to determine the level of crop injury, weed control and white bean yield with up to four-way mixtures of herbicides applied preplant incorporated (PPI). The trials were arranged in a factorial design: Factor 1 was "Grass herbicide" including no grass herbicide, trifluralin, S-metolachlor and trifluralin + S-metolachlor and Factor 2 was "Broadleaf herbicide" including no broadleaf herbicide, halosulfuron, imazethapyr and halosulfuron + imazethapyr. At 2 and 4 weeks after emergence (WAE), there was minimal $(\leq 4 \%)$ white bean injury. At 8 weeks after herbicide application (WAA), trifluralin, S-metolachlor or trifluralin + S-metolachlor averaged across Factor 2 controlled velvetleaf 69,71 and $62 \%$, respectively; halosulfuron, imazethapyr and halosulfuron + imazethapyr averaged across Factor 1 controlled velvetleaf 75, 95 and 97\%, respectively. At 8 WAA, trifluralin, S-metolachlor and trifluralin + S-metolachlor controlled pigweed 93, 90 and 97\%, respectively, and halosulfuron, imazethapyr and halosulfuron + imazethapyr controlled pigweed 97, 79 and 98\%, respectively. At 8 WAA, trifluralin, S-metolachlor and trifluralin + S-metolachlor provided poor $(\leq 32 \%)$ control of common ragweed while halosulfuron, imazethapyr and halosulfuron + imazethapyr controlled common ragweed 86,53 and $87 \%$, respectively. The 4-way tankmix of trifluralin, S-metolachlor, halosulfuron + imazethapyr controlled common ragweed $95 \%$. At 8 WAA, trifluralin, S-metolachlor and trifluralin + S-metolachlor controlled common lambsquarters 81, 38 and 91\%, respectively, and halosulfuron, imazethapyr and halosulfuron + imazethapyr controlled common lambsquarters 94, 97 and 99\%, respectively. At 8 WAA, trifluralin, S-metolachlor and trifluralin + S-metolachlor provided poor $(\leq 46 \%)$ control of wild mustard while halosulfuron, imazethapyr and halosulfuron + imazethapyr provided excellent $(\geq 97 \%)$ wild mustard control. At 8 WAA, trifluralin, S-metolachlor and trifluralin + S-metolachlor controlled barnyardgrass 70,85 and $94 \%$, respectively, and halosulfuron, imazethapyr and halosulfuron + imazethapyr controlled barnyardgrass 9,50 and 59\%, respectively. At 8 WAA, trifluralin, S-metolachlor and trifluralin + S-metolachlor controlled green foxtail 89 to $98 \%$ and halosulfuron, imazethapyr and halosulfuron + imazethapyr controlled green foxtail 19,69 and 67\%, respectively. Weed interference reduced white bean yield $76 \%$. Generally, white bean yield reflected the level of weed control. Based on these results, the 2- and 3-way tankmixes of herbicides evaluated generally provide similar weed control as the 4-way tankmixes.
\end{abstract}

Keywords: broadleaf control, halosulfuron, imazethapyr, S-metolachlor, tankmix, trifluralin, yield

\section{Introduction}

Dry bean (Phaseolus vulgaris L.) is a legume crop grown and consumed in many parts of the world (OBG, 2021). Canada is an important dry bean producer in the world. White (navy) bean has been grown in Ontario since the early 1900's and is the most popular dry bean market class grown in the province (OBG, 2021). Most of the white bean produced in Ontario is exported to the United Kingdom for baked beans and the rest is consumed domestically (OBG, 2021). Farmers in Ontario produce approximately 56,000 tonnes of white bean grown on 27,000 hectares with a farm gate value of nearly $\$ 50$ million (OMAFRA, 2021). Weeds can reduce white bean yield substantially if not controlled. Manuscripts published by the Yield Loss Committee of the Weed Science Society of America (WSSA) estimated yield loss of $71 \%$ in dry bean due to weed interference which was substantially greater than other field crops such as corn (50\%), soybean $(52 \%)$ and winter wheat (23\%) (Flessner, 2021; Soltani et al., 2016, 2017, 2018). Despite a drastic potential yield loss due to weed interference, the number of herbicides available to white bean growers is much fewer than corn, soybean and winter wheat 
(OMAFRA, 2020). Soil-applied herbicides commonly used by white bean producers include trifluralin, S-metolachlor, halosulfuron and imazethapyr (OMAFRA, 2020).

Trifluralin is a Group 3 herbicide from the dinitroaniline chemical family that controls several annual grasses including green foxtail (Setaria viridis (L.) Beauv.), yellow foxtail (Setaria glauca (L.) Beauv.), giant foxtail (Setaria faberii Herrm.), barnyardgrass (Echinochloa crusgalli (L.) Beauv.), smooth crabgrass (Digitaria ischaemum (Schreb) Muhl.), large crabgrass (Digitaria sanguinalis (L.) Scop), and fall panicum (Panicum dichotomiflorum Michx.) (OMAFRA, 2020; Shaner, 2014). Trifluralin provides control/suppression of some broadleaf weeds such as common lambsquarters (Chenopodium album L.) and redroot pigweed (Amaranthus retroflexus L.) including Group 2 and 5 resistant biotypes (Shaner, 2014; OMAFRA, 2020).

S-metolachlor is a Group 15 herbicide from the chloroacetanilide chemical family that controls grass species including foxtail species, barnyardgrass, crabgrass species, fall panicum, and witchgrass (Panicum. Capillare L.) (Shaner, 2014; OMAFRA, 2020). S-metolachlor provides partial control of broadleaf weeds such as common lambsquarters, Amaranthus spp. and Solanum spp. including Group 2 and 5 resistant biotypes (OMAFRA, 2020).

Halosulfuron is a Group 2 broadleaf herbicide from the sulfonylurea chemical family that control weeds by inhibiting the production of valine, leucine and isoleucine amino acids in plants (Duggleby et al., 2008). Weeds controlled by halosulfuron include yellow nutsedge (Cyperus esculentus L.), wild mustard (Sinapis arvensis L.), common lambsquarters, redroot pigweed, velvetleaf (Abutilon theophrasti Medic.), and common ragweed (Ambrosia artemisiifolia L.) including Group 5 and 9 resistant biotypes (OMAFRA, 2020).

Imazethapyr is a Group 2 herbicide from the imidazolinone chemical family that controls broadleaf species such as common lambsquarters, velvetleaf, Amaranthus spp., wild buckwheat (Polygonum convolulus L.), ladysthumb (Polygonum persicaria L.), wild mustard and common ragweed, including Group 5 and 9 resistant biotypes (OMAFRA, 2020). Imazethapyr can also provide some control of grass weed species such as foxtails and barnyardgrass (Li et al., 2017).

Growers often need to tankmix grass herbicides such as trifluralin and S-metolachlor with broadleaf herbicides such as halosulfuron and imazethapyr for broad-spectrum weed control in white bean production. Earlier studies with trifluralin, S-metolachlor, halosulfuron, and imazethapyr have mostly focused on two-way tankmixes of these herbicides for broad-spectrum weed control in white bean (Li et al., 2016, 2017; Soltani et al., 2010; Soltani et al., 2012a, 2012b; Soltani et al., 2014a). White bean growers have seen inconsistent control of some problematic weed species such as common ragweed with two-way tankmixes in Ontario. Three- or four-way tank-mixtures of these herbicides may improve the efficacy and consistency of weed control in white bean production. To our knowledge, no previous study has cumulatively compared the crop safety and weed control efficacy of a four-way tankmix of trifluralin, S-metolachlor, halosulfuron, and imazethapyr, applied PPI in white bean under Ontario environmental conditions. More research is needed to evaluate crop safety and consistency of weed control with various tankmix combinations of these herbicides to improve weed control efficacy, increase seed yield, and elevate net returns to white bean growers in Ontario.

The objectives of this study were to determine the level of crop injury, weed control and white bean yield with trifluralin $\left(600 \mathrm{~g}\right.$ ai ha $\left.^{-1}\right)$, S-metolachlor $\left(1050 \mathrm{~g}\right.$ ai ha $\left.^{-1}\right)$, halosulfuron $\left(26.25 \mathrm{~g}_{\text {ai ha }}{ }^{-1}\right)$, and imazethapyr $(37.5 \mathrm{~g}$ ai $\mathrm{ha}^{-1}$ ), applied preplant incorporated (PPI) alone and in two-, three- and four-way tank-mixtures.

\section{Materials and Methods}

A total of five field experiments were completed over at three-year period with three at the Huron Research Station (one in 2018, 2019 and 2020) near Exeter, Ontario $\left(43^{\circ} 19^{\prime} 1.21^{\prime \prime} \mathrm{N}, 81^{\circ} 30^{\prime} 3.87^{\prime \prime} \mathrm{E}\right.$ ) and two at the University of Guelph Ridgetown Campus (one in 2019 and 2020) near Ridgetown, Ontario $\left(42^{\circ} 26^{\prime} 26^{\prime \prime} \mathrm{N}\right.$, $81^{\circ} 53^{\prime} 3^{\prime \prime} \mathrm{W}$ ). The soil at Exeter was a Brookston clay loam (Orthic Humic Gleysol, mixed, mesic, and poorly drained) and the soil at the Ridgetown location was a Watford/Brady sandy loam. Seedbed preparation at all sites consisted of fall moldboard plowing followed by seedbed preparation in the spring with a field cultivator with rolling basket harrows.

The experimental design was a two-way factorial, established in the field as a randomized complete block design (RCBD) with 4 replicates. Factor 1 was "Grass herbicide" and Factor 2 was "Broadleaf herbicide". Treatments are listed in Table 1. Each plot was $3.0 \mathrm{~m}$ wide and $10 \mathrm{~m}$ long at Exeter and $8 \mathrm{~m}$ long at Ridgetown and consisted of four rows of 'T9905' white bean spaced $0.75 \mathrm{~m}$ apart. White bean was planted at a rate of approximately 240,000 seeds $^{-1} \mathrm{a}^{-1}$ late May to early June of each year. 
Table 1. White bean injury, moisture at harvest and yield in response to preplant incorporated applications of various combinations of grass and broadleaf herbicides for five factorial trials conducted at Exeter and Ridgetown, ON (2018-2020). Means for a main effect were separated only if the interaction involving the main effect was negligible

\begin{tabular}{|c|c|c|c|c|c|}
\hline \multirow{2}{*}{ Main effects } & & \multicolumn{2}{|c|}{ Visible Injury $(\%)^{\top}$} & \multirow{2}{*}{ Moisture (\%) } & \multirow{2}{*}{ Yield $\left(\mathrm{T} \mathrm{ha}^{-1}\right)^{2}$} \\
\hline & & $2 \mathrm{WAE}$ & $4 \mathrm{WAE}$ & & \\
\hline Grass herbicide & Rate $\left(g\right.$ ai $\left.h a^{-1}\right)$ & & & & \\
\hline Check & 0 & $1.8 \mathrm{a}$ & 1.5 & $18.0 \mathrm{~b}$ & 1.57 \\
\hline Trifluralin & 600 & $2.2 \mathrm{ab}$ & 1.7 & $17.5 \mathrm{a}$ & 2.33 \\
\hline$S$-metolachlor & 1050 & $2.9 \mathrm{~b}$ & 2.0 & $17.6 \mathrm{ab}$ & 2.41 \\
\hline Trifluralin $+S$-metolachlor & $600+1050$ & $2.8 \mathrm{ab}$ & 2.5 & $17.4 \mathrm{a}$ & 2.56 \\
\hline GRASS P-value & & 0.026 & 0.1853 & 0.0122 & $<0.0001$ \\
\hline \multicolumn{6}{|l|}{ Broadleaf herbicide } \\
\hline Check & 0 & $0.6 \mathrm{a}$ & $0.1 \mathrm{a}$ & $17.9 \mathrm{~b}$ & 1.58 \\
\hline Halosulfuron & 26 & $1.9 \mathrm{~b}$ & $0.8 \mathrm{a}$ & $17.6 \mathrm{ab}$ & 2.28 \\
\hline Imazethapyr & 37.5 & $3.2 \mathrm{c}$ & $2.7 \mathrm{~b}$ & $17.6 \mathrm{ab}$ & 2.39 \\
\hline Halosulfuron + imazethapyr & $26+37.5$ & $3.9 \mathrm{c}$ & $4.1 \mathrm{c}$ & $17.4 \mathrm{a}$ & 2.61 \\
\hline BL P-value & & $<0.0001$ & $<0.0001$ & 0.0155 & $<0.0001$ \\
\hline \multicolumn{6}{|l|}{ Interaction } \\
\hline GRASS $\times$ BL P-value & & 0.0996 & 0.3778 & 0.2715 & 0.0169 \\
\hline
\end{tabular}

\begin{tabular}{|c|c|c|c|c|}
\hline \multirow{2}{*}{$\begin{array}{l}\text { Simple effects } \\
\text { Grass herbicide }\end{array}$} & \multicolumn{4}{|c|}{ Broadleaf herbicide } \\
\hline & Check & Halosulfuron & Imazethapyr & Halosulfuron + imazethapyr \\
\hline Yield $\left(T h a^{-1}\right)$ & & & & \\
\hline Check & $0.66 \mathrm{~b} \quad \mathrm{X}$ & $1.45 \mathrm{~b}$ & $1.99 \mathrm{~b}$ & $2.18 \mathrm{~b} \quad \mathrm{Z}$ \\
\hline Trifluralin & $1.79 \mathrm{a} \quad \mathrm{Y}$ & $2.30 \mathrm{a}$ & $2.57 \mathrm{a}$ & $2.67 \mathrm{ab} \mathrm{Z}$ \\
\hline$S$-metolachlor & $1.69 \mathrm{a} \quad \mathrm{Y}$ & $2.61 \mathrm{a}$ & $2.53 \mathrm{a} \quad \mathrm{Z}$ & $2.80 \mathrm{a} \mathrm{Z}$ \\
\hline Trifluralin $+S$-metolachlor & $2.20 \mathrm{a} \quad \mathrm{Y}$ & $2.77 \mathrm{a}$ & 2.48 ab YZ & $2.77 \mathrm{a} \mathrm{Z}$ \\
\hline
\end{tabular}

Note. BL: broadleaf herbicide; GRASS: grass herbicide; WAE: weeks after crop emergence.

Means followed by a different letter within a column $(\mathrm{a}-\mathrm{b})$ or row $(\mathrm{X}-\mathrm{Z})$ within each section are significantly different according to a Tukey-Kramer multiple range test at $\mathrm{P}<0.05$.

${ }^{1}$ Means for white bean injury are based on data from Exeter in 2018 to 2020; Ridgetown trials showed no visible injury and were excluded from analysis due to zero variance.

${ }^{2}$ No yield data for Ridgetown in 2020 .

Herbicide treatments were applied using a $\mathrm{CO}_{2}$-pressurized backpack sprayer calibrated to deliver $200 \mathrm{~L} \mathrm{ha}^{-1}$ at $240 \mathrm{kPa}$. The boom was $1.5 \mathrm{~m}$ long with four ultra-low drift nozzles (ULD120-02, Hypro, New Brighton, MN) spaced $50 \mathrm{~cm}$ apart. The surface area sprayed was the center $2.0 \mathrm{~m}$ of each plot. There was a $1.0 \mathrm{~m}$ unsprayed area between adjacent plots. Preplant incorporated herbicides were applied 1-2 days before planting and were immediately incorporated into the soil with two passes (in opposite directions) of an S-tine cultivator with rolling basket harrows.

White bean injury [2 and 4 weeks after crop emergence (WAE)] and weed control [4 and 8 weeks after herbicide application (WAA)] were visually estimated on a scale of $0 \%$ (no injury/control) to $100 \%$ (complete plant death). Weed density and dry weight were evaluated 8 WAA by counting and cutting plants at the soil surface in two 0.5 $\mathrm{m}^{2}$ quadrats per plot and separating by species. Each weed species was dried at $60{ }^{\circ} \mathrm{C}$ to a constant moisture and then weighed. White bean was combined at harvest maturity using a small plot combine; seed moisture content and weight were recorded. Seed moisture content was adjusted to $18 \%$ prior to analysis.

Data analysis was carried out using Proc Glimmix in SAS (Ver. 9.4, SAS Institute Inc., Cary, NC), with grass herbicide, broadleaf herbicide and their interaction as the fixed effects, and year-location combinations (environment), replicate within environment and environment by grass herbicide by broadleaf herbicide interaction as the random effects. Evaluation of potential distributions for each parameter was accomplished by using studentized residual plots to control for departures from the assumption of homogeneous variance, the Shapiro-Wilk statistic and normal probability plot to confirm the assumption of normality, the Chi-square/df ratio to check for overdispersion, and information criteria such as AICC to compare fit between models where 
possible. White bean injury and yield were analyzed using the normal distribution, percent visible weed control was arcsine square-root transformed prior to analysis with the normal distribution, and weed density, weed biomass and white bean moisture at harvest were analyzed using the lognormal distribution. All least square mean pairwise comparisons were adjusted using the Tukey-Kramer method and the significance level was set at $p<0.05$. Main effect least-square means were separated only if the grass herbicide by broadleaf herbicide interaction was negligible; when this interaction was non-negligible, least-square means comparisons for simple effects are presented. All comparisons were conducted on the model scale. However, means for data analyzed using a non-normal distribution or requiring transformation for analysis were back-transformed for presentation of results.

\section{Results and Discussion}

\subsection{White Bean Injury and Yield}

There was minimal visible white bean injury $(\leq 4.1 \%)$. at 2 and 4 WAE (Table 1$)$. At 2 WAE, trifluralin, S-metolachlor or trifluralin + S-metolachlor averaged across Factor 2 caused 2\% to 3\% white bean injury which decreased slightly at 4 WAE. Halosulfuron, imazethapyr and halosulfuron + imazethapyr averaged across Factor 1 caused 2 to $4 \%$ and 1 to $4 \%$ white bean injury at 2 and 4 WAE, respectively. There was no difference in white bean seed moisture content within the "Grass herbicide" or "Broadleaf herbicide". There was trend to slightly lower seed moisture content with the use of a herbicide although differences were not always statistically significant, which indicates that the presence of weeds results a slight delay in white bean maturity. Weed interference reduced white bean yield as much as $76 \%$ in this study (Table 1). Reduced weed interference with trifluralin, S-metolachlor, halosulfuron, or imazethapyr applied alone or in a two-, three- or four-way tank-mixtures resulted in increased white bean yield. Generally, white bean yield reflected the level of weed control. Results are similar to other studies in which weed interference reduced white bean seed yield by $70 \%$ (Soltani et al., 2020). In the same study two-way tankmixes of trifluralin + halosulfuron and S-metolachlor + halosulfuron, applied PPI resulted in white bean yields that were up to $95 \%$ of the weed-free control (Soltani et al., 2020).

\subsection{Weed Control}

Weeds selected for analysis needed to be present (and have usable data) in at least 2 out of the 5 environments and included: velvetleaf (2/5), pigweed (green and redroot combined) (4/5), common ragweed (5/5), common lambsquarters (5/5), wild mustard (3/5), barnyardgrass (2/5), and green foxtail (5/5).

\subsubsection{Velvetleaf}

There was no interaction between "Grass herbicide" and "Broadleaf herbicide" for the velvetleaf control (4 and 8 WAA) and density so the main effects are presented (Table 2). There was an interaction between "Grass herbicide" and "Broadleaf herbicide" for velvetleaf biomass so the simple effects is presented. Trifluralin, S-metolachlor and trifluralin + S-metolachlor averaged across "Broadleaf herbicide" controlled velvetleaf $73-82 \%$ and $62-71 \%$ at 4 and 8 WAA, respectively (Table 2). Trifluralin, S-metolachlor and trifluralin + S-metolachlor averaged across "Broadleaf herbicide" did not reduce velvetleaf density. Halosulfuron, imazethapyr and halosulfuron + imazethapyr averaged across "Grass herbicide" controlled velvetleaf $89 \%, 97 \%$ and $99 \%$ and $75 \%, 95 \%$ and $97 \%$ at 4 and $8 \mathrm{WAA}$, respectively. Imazethapyr provided greater velvetleaf control than halosulfuron. Halosulfuron, imazethapyr and halosulfuron + imazethapyr averaged across "Grass herbicide" reduced velvetleaf density 34\%, $88 \%$ and $88 \%$, respectively. There was a significant "Grass herbicide" by "Broadleaf herbicide" interaction for velvetleaf biomass reduction. Trifluralin, S-metolachlor and trifluralin + S-metolachlor did not reduce velvetleaf biomass nor did halosulfuron, imazethapyr and halosulfuron + imazethapyr. The addition of halosulfuron + imazethapyr to trifluralin reduced velvetleaf biomass $92 \%$, the addition of imazethapyr or halosulfuron + imazethapyr to S-metolachlor decreased velvetleaf biomass $97 \%$ and $88 \%$, respectively. the addition of imazethapyr to trifluralin + S-metolachlor decreased velvetleaf biomass $100 \%$. In contrast, the addition of a "Grass Herbicide" to halosulfuron, imazethapyr or halosulfuron + imazethapyr did not reduced velvetleaf biomass. These findings are similar to other studies in which grass herbicides such as trifluralin and S-metolachlor did not control velvetleaf but imazethapyr and halosulfuron controlled velvetleaf greater than 95\% (Brown \& Masiunas, 2002). Two-way tankmix combination of trifluralin + halosulfuron and S-metolachlor + halosulfuron applied PPI were shown to provide up to $97 \%$ control of velvetleaf (Soltani et al., 2020). 
Table 2. Velvetleaf control, density and biomass in response to preplant incorporated applications of various combinations of grass and broadleaf herbicides for two factorial trials conducted at Ridgetown, ON (2019-2020). Means for a main effect were separated only if the interaction involving the main effect was negligible

\begin{tabular}{|c|c|c|c|c|c|c|}
\hline \multirow{2}{*}{ Main effects } & & \multicolumn{2}{|c|}{ Control (\%) } & \multirow{2}{*}{\multicolumn{2}{|c|}{ Density (plants $\mathrm{m}^{-2}$ ) }} & \multirow{2}{*}{ Biomass $\left(\mathrm{g} \mathrm{m}^{-2}\right)$} \\
\hline & & \multirow[t]{2}{*}{4 WAA } & 8 WAA & & & \\
\hline Grass herbicide & Rate $\left(g\right.$ ai $\left.h a^{-1}\right)$ & & & & & \\
\hline Check & 0 & $66 \mathrm{~b}$ & 62 & 1.6 & & 0.8 \\
\hline Trifluralin & 600 & $80 \mathrm{ab}$ & 69 & 1.7 & & 0.9 \\
\hline$S$-metolachlor & 1050 & $82 \mathrm{a}$ & 71 & 1.7 & & 1.1 \\
\hline Trifluralin $+S$-metolachlor & $600+1050$ & $73 \mathrm{ab}$ & 62 & 1.8 & & 1.2 \\
\hline GRASS P-value & & 0.0230 & 0.4070 & 0.9959 & & 0.6833 \\
\hline \multicolumn{7}{|l|}{ Broadleaf herbicide } \\
\hline Check & 0 & $1 \mathrm{c}$ & $0 \mathrm{c}$ & $4.1 \mathrm{c}$ & & 2.2 \\
\hline Halosulfuron & 26 & $89 \mathrm{~b}$ & $75 \mathrm{~b}$ & $2.7 \mathrm{~b}$ & & 1.4 \\
\hline Imazethapyr & 37.5 & $97 \mathrm{a}$ & $95 \mathrm{a}$ & $0.5 \mathrm{a}$ & & 0.3 \\
\hline Halosulfuron + imazethapyr & $26+37.5$ & $99 \mathrm{a}$ & $97 \mathrm{a}$ & $0.5 \mathrm{a}$ & & 0.5 \\
\hline BL P-value & & $<0.0001$ & $<0.0001$ & $<0.0001$ & & $<0.0001$ \\
\hline \multicolumn{7}{|l|}{ Interaction } \\
\hline \multicolumn{2}{|l|}{ GRASS $\times$ BL P-value } & 0.5351 & 0.3804 & \multicolumn{2}{|l|}{0.1351} & 0.0183 \\
\hline \multirow{2}{*}{$\begin{array}{l}\text { Simple effects } \\
\text { Grass herbicide }\end{array}$} & \multicolumn{6}{|c|}{ Broadleaf herbicide } \\
\hline & Check & Halosulfuron & Imaz & thapyr & Halosulfurc & on + imazethapyr \\
\hline \multicolumn{7}{|l|}{ Biomass $\left(\mathrm{g} \mathrm{m}^{-2}\right)$} \\
\hline Check & $1.3 \mathrm{a}$ & $1.3 \mathrm{ab}$ & $0.2 \mathrm{a}$ & & $0.9 \mathrm{a}$ & \\
\hline Trifluralin & $2.6 \mathrm{ab} \mathrm{Y}$ & 0.5 a $\quad Y Z$ & $0.9 \mathrm{a}$ & YZ & $0.2 \mathrm{a}$ & \\
\hline$S$-metolachlor & $3.3 \mathrm{~b} \quad \mathrm{Y}$ & $1.2 \mathrm{ab} \mathrm{YZ}$ & $0.1 \mathrm{a}$ & Z & $0.4 \mathrm{a}$ & \\
\hline Trifluralin $+S$-metolachlor & $1.8 \mathrm{ab} \mathrm{XY}$ & $3.3 \mathrm{~b} \quad \mathrm{X}$ & $0.0 \mathrm{a}$ & Z & 0.8 a $\mathrm{YZ}$ & \\
\hline
\end{tabular}

Note. BL: broadleaf herbicide; GRASS: grass herbicide; WAA: weeks after herbicide application.

Means followed by a different letter within a column (a-b) or row (X-Z) within each section are significantly different according to a Tukey-Kramer multiple range test at $\mathrm{P}<0.05$. Rows without an uppercase letter have no difference between the check and broadleaf treatment.

\subsubsection{Pigweed (Green and Redroot Pigweed Combined)}

There was an interaction between "Grass herbicide" and "Broadleaf herbicide" for the pigweed control (4 and 8 WAA), density and biomass (Table 3) so the simple effects are presented (Table 4). At 4 WAA, trifluralin controlled pigweed $93 \%$, control was increased to $100 \%$ with the addition of halosulfuron + imazethapyr. S-metolachlor controlled pigweed $90 \%$, control was increased to $99-100 \%$ with the addition of halosulfuron, imazethapyr, or halosulfuron + imazethapyr. Trifluralin + S-metolachlor controlled pigweed $97 \%$, there was no improvement in pigweed control with the addition of halosulfuron, imazethapyr, or halosulfuron + imazethapyr. Halosulfuron and halosulfuron + imazethapyr controlled pigweed 97 and 99\%, respectively, there was no improvement in control with the addition of trifluralin, S-metolachlor or trifluralin + S-metolachlor. In contrast, imazethapyr controlled pigweed $83 \%$, the addition of trifluralin, S-metolachlor and trifluralin + S-metolachlor improved pigweed control to $98-99 \%$. At 8 WAA, trifluralin, S-metolachlor and trifluralin + S-metolachlor controlled pigweed $92 \%, 85 \%$ and $95 \%$, respectively; the the addition of halosulfuron + imazethapyr to S-metolachlor improved pigweed control to $99 \%$. Trifluralin, S-metolachlor and trifluralin + S-metolachlor reduced pigweed density $93 \%, 90 \%$ and $96 \%$, respectively. The addition of imazethapyr or halosulfuron + imazethapyr to trifluralin reduced pigweed density; the addition of halosulfuron, imazethapyr or halosulfuron + imazethapyr to S-metolachlor reduced pigweed density; and the addition of halosulfuron + imazethapyr to trifluralin + S-metolachlor reduced pigweed density. Halosulfuron, imazethapyr or halosulfuron + imazethapyr reduced pigweed density $96 \%, 95 \%$ and $99 \%$, respectively. The addition of trifluralin, S-metolachlor or trifluralin + S-metolachlor to halosulfuron or halosulfuron + imazethapyr did not reduce pigweed density. In contrast, the addition of S-metolachlor or trifluralin + S-metolachlor to imazethapyr reduced pigweed density from $95 \%$ to $99 \%$. 
Table 3. Pigweed control, density and biomass in response to preplant incorporated applications of various combinations of grass and broadleaf herbicides for four factorial trials conducted at Exeter and Ridgetown, ON (2019-2020). Means for a main effect were separated only if the interaction involving the main effect was negligible

\begin{tabular}{|c|c|c|c|c|c|}
\hline \multirow{2}{*}{ Main effects } & & \multicolumn{2}{|c|}{ Control (\%) } & \multirow{2}{*}{ Density (plants $\mathrm{m}^{-2}$ ) } & \multirow{2}{*}{ Biomass $\left(\mathrm{g} \mathrm{m}^{-2}\right)$} \\
\hline & & 4 WAA & 8 WAA & & \\
\hline Grass herbicide & Rate $\left(g\right.$ ai $\left.h a^{-1}\right)$ & & & & \\
\hline Check & 0 & 71 & 69 & 17.9 & 27.6 \\
\hline Trifluralin & 600 & 98 & 97 & 2.2 & 8.3 \\
\hline$S$-metolachlor & 1050 & 98 & 96 & 2.1 & 10.2 \\
\hline Trifluralin $+S$-metolachlor & $600+1050$ & 99 & 98 & 1.3 & 5.2 \\
\hline GRASS P-value & & $<0.0001$ & $<0.0001$ & $<0.0001$ & 0.0001 \\
\hline \multicolumn{6}{|l|}{ Broadleaf herbicide } \\
\hline Check & 0 & 70 & 66 & 22.1 & 53.9 \\
\hline Halosulfuron & 26 & 98 & 97 & 1.9 & 7.6 \\
\hline Imazethapyr & 37.5 & 96 & 94 & 1.6 & 7.5 \\
\hline Halosulfuron + imazethapyr & $26+37.5$ & 100 & 99 & 0.5 & 2.6 \\
\hline BL P-value & & $<0.0001$ & $<0.0001$ & $<0.0001$ & $<0.0001$ \\
\hline \multicolumn{6}{|l|}{ Interaction } \\
\hline GRASS $\times$ BL P-value & & $<0.0001$ & $<0.0001$ & $<0.0001$ & $<0.0017$ \\
\hline
\end{tabular}

Note. BL: broadleaf herbicide; GRASS: grass herbicide; WAA: weeks after herbicide application.

Table 4. Simple effects for pigweed control, density and biomass in response to preplant incorporated applications of various combinations of grass and broadleaf herbicides for four factorial trials conducted at Exeter and Ridgetown, ON (2019-2020)

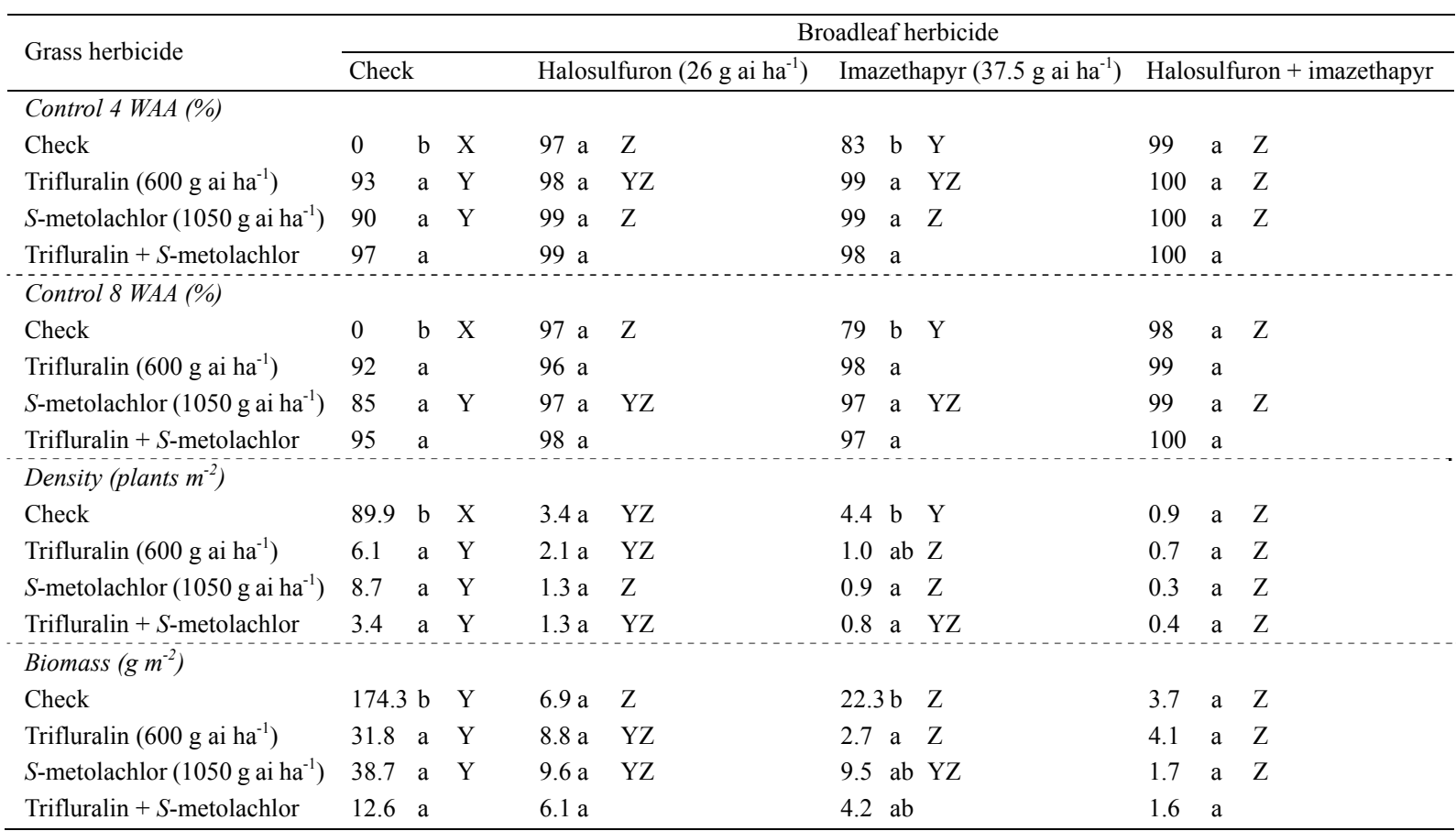

Note. WAA: weeks after herbicide application.

Means followed by a different letter within a column (a-b) or row (X-Z) within each section are significantly different according to a Tukey-Kramer multiple range test at $\mathrm{P}<0.05$. Rows without an uppercase letter have no difference between the check and broadleaf treatment.

Trifluralin, S-metolachlor and trifluralin + S-metolachlor reduced pigweed biomass $82 \%, 78 \%$ and $93 \%$, respectively. The addition of imazethapyr or halosulfuron + imazethapyr to trifluralin reduced pigweed biomass and the addition of halosulfuron + imazethapyr to S-metolachlor reduced pigweed biomass. Halosulfuron, 
imazethapyr or halosulfuron + imazethapyr reduced pigweed density $96 \%, 87 \%$ and $98 \%$, respectively. The addition of trifluralin, S-metolachlor or trifluralin + S-metolachlor to halosulfuron or halosulfuron + imazethapyr did not reduce pigweed biomass. In contrast, the addition of trifluralin to imazethapyr reduced pigweed density from $87 \%$ to $98 \%$. In other studies, redroot pigweed was controlled $72-98 \%$ with trifluralin PPI (Li et al., 2016; 2017; Soltani et al., 2010; Soltani et al., 2012a, 2012b; Soltani et al., 2014a); 84-95\% with S-metolachlor PPI (Li et al., 2016, 2017; Soltani et al., 2014a); 62-99\% with imazethapyr PPI (Li et al., 2017; Soltani et al., 2012a; Soltani et al., 2014a); and 83-100\% with halosulfuron PPI (Li et al., 2016, 2017; Soltani et al., 2014a, 2014b). In another study, trifluralin, S-metolachlor and halosulfuron applied PPI alone provided up to $97 \%$ control of pigweeds while the two-way tankmix of trifluralin + halosulfuron and S-metolachlor + halosulfuron applied PPI provided up to $100 \%$ control of pigweeds in white bean (Soltani et al., 2020).

\subsubsection{Common Ragweed}

There was as an interaction between "Grass herbicide" and "Broadleaf herbicide" for common ragweed control (4 and 8 WAA) so the simple effects are presented (Table 5). There was no interaction between "Grass herbicide" and "Broadleaf herbicide" for common ragweed density and biomass so the main effects are presented. At 4 WAA, trifluralin, S-metolachlor and trifluralin + S-metolachlor controlled common ragweed 26-42\% (Table 5). Common ragweed control was $47 \%, 45 \%$ and $55 \%$ higher when halosulfuron, imazethapyr or halosulfuron + imazethapyr were added to trifluralin; $71 \%, 62 \%$ and $71 \%$ higher when halosulfuron, imazethapyr or halosulfuron + imazethapyr were added to S-metolachlor; and 59\%, 49\% and 59\% higher when halosulfuron, imazethapyr or halosulfuron + imazethapyr were added to trifluralin + S-metolachlor, respectively. Halosulfuron, imazethapyr or halosulfuron + imazethapyr controlled common ragweed $93 \%, 67 \%$ and $97 \%$, respectively; there was no improvement in common ragweed control with the addition of trifluralin, S-metolachlor and trifluralin + S-metolachlor. At 8 WAA, trifluralin, S-metolachlor and trifluralin + S-metolachlor controlled common ragweed $7 \%, 10 \%$ and $32 \%$, respectively, Common ragweed control was $74 \%, 63 \%$, and $88 \%$ higher when halosulfuron, imazethapyr or halosulfuron + imazethapyr were added to trifluralin; $84 \%, 67 \%$ and $82 \%$ higher when halosulfuron, imazethapyr or halosulfuron + imazethapyr were added to S-metolachlor; and $63 \%, 43 \%$ and $63 \%$ higher when halosulfuron, imazethapyr or halosulfuron + imazethapyr were added to trifluralin + S-metolachlor, respectively. Halosulfuron, imazethapyr or halosulfuron + imazethapyr controlled common ragweed $86 \%, 53 \%$ and $87 \%$, respectively; there was no improvement in common ragweed control with the addition of trifluralin, S-metolachlor or trifluralin + S-metolachlor. There was no significant grass herbicide by broadleaf herbicide interaction for common ragweed density or biomass. Trifluralin, S-metolachlor and trifluralin + S-metolachlor averaged across "Broadleaf herbicide" did not reduce common ragweed density or biomass. Halosulfuron, imazethapyr and halosulfuron + imazethapyr averaged across "Grass herbicide" reduced common ragweed density $88 \%, 69 \%$ and $92 \%$ and biomass $91 \%, 57 \%$ and $90 \%$, respectively. In other studies, common ragweed was controlled 9-28\% with trifluralin PPI (Li et al., 2016, 2017; Soltani et al., 2012a, 2012b; Soltani et al., 2010; Soltani et al., 2014a); 13-40\% with S-metolachlor PPI (Li et al., 2016, 2017; Soltani et al., 2014a); 73-97\% with imazethapyr PPI (Li et al., 2017; Soltani et al., 2012a; Soltani et al., 2014a); and 95-99\% with halosulfuron PPI (Li et al., 2016, 2017; Soltani et al., 2014a). The two-way tankmixes of trifluralin + halosulfuron and S-metolachlor + halosulfuron applied PPI were shown to provide up to 94 and $96 \%$ control of common ragweed in white bean, respectively (Soltani et al., 2020). 
Table 5. Common ragweed control, density and biomass in response to preplant incorporated applications of various combinations of grass and broadleaf herbicides for five factorial trials conducted at Exeter and Ridgetown, ON (2018-2020). Means for a main effect were separated only if the interaction involving the main effect was negligible

\begin{tabular}{|c|c|c|c|c|c|c|}
\hline \multirow{2}{*}{ Main effects } & & \multicolumn{2}{|c|}{ Control $(\%)$} & \multirow{2}{*}{\multicolumn{2}{|c|}{ Density (plants $\mathrm{m}^{-2}$ ) }} & \multirow{2}{*}{ Biomass $\left(\mathrm{g} \mathrm{m}^{-2}\right)$} \\
\hline & & \multirow{2}{*}{4 WAA } & 8 WAA & & & \\
\hline Grass herbicide & Rate $\left(g\right.$ ai $\left.h a^{-1}\right)$ & & \multirow[b]{2}{*}{52} & & & \\
\hline Check & 0 & 63 & & \multicolumn{2}{|l|}{4.8} & 13.1 \\
\hline Trifluralin & 600 & 82 & 64 & \multicolumn{2}{|l|}{4.7} & 22.5 \\
\hline$S$-metolachlor & 1050 & 82 & 71 & \multicolumn{2}{|l|}{3.8} & 15.3 \\
\hline Trifluralin $+S$-metolachlor & \multirow[t]{2}{*}{$600+1050$} & 86 & 78 & \multicolumn{2}{|l|}{3.7} & 14.2 \\
\hline GRASS P-value & & $<0.0001$ & $<0.0001$ & 0.3377 & & 0.1062 \\
\hline \multicolumn{7}{|l|}{ Broadleaf herbicide } \\
\hline Check & 0 & 21 & 9 & \multicolumn{2}{|l|}{$14.3 \mathrm{c}$} & $53.5 \mathrm{c}$ \\
\hline Halosulfuron & 26 & 95 & 90 & \multicolumn{2}{|l|}{$1.7 \mathrm{a}$} & $4.9 \mathrm{a}$ \\
\hline Imazethapyr & 37.5 & 83 & 69 & \multicolumn{2}{|l|}{$4.4 \mathrm{~b}$} & $22.9 \mathrm{~b}$ \\
\hline Halosulfuron + imazethapyr & \multirow{2}{*}{$26+37.5$} & 97 & 92 & \multicolumn{2}{|l|}{$1.2 \mathrm{a}$} & $5.1 \mathrm{a}$ \\
\hline BL P-value & & $<0.0001$ & $<0.0001$ & $<0.0001$ & & $<0.0001$ \\
\hline Interaction & & & & & & \\
\hline GRASS $\times$ BL P-value & & 0.0014 & 0.0258 & 0.7235 & & 0.1456 \\
\hline Simple effects & & & Broadleaf & herbicide & & \\
\hline Grass herbicide & Check & Halosulfuron & Imaz & ethapyr & Halosulfurc & n + imazethapyr \\
\hline Control 4 WAA (\%) & & & & & & \\
\hline Check & $\begin{array}{lll}0 & \mathrm{~b} & \mathrm{X}\end{array}$ & 93 a $\mathrm{Z}$ & $67 a$ & $Y$ & 97 a $Z$ & \\
\hline Trifluralin & 42 a $Y$ & 89 a $\mathrm{Z}$ & $87 a$ & $Z$ & 97 a $Z$ & \\
\hline$S$-metolachlor & 26 a $\mathrm{Y}$ & 97 a $Z$ & 88 a & $Z$ & 97 a $Z$ & \\
\hline Trifluralin $+S$-metolachlor & 39 a $\mathrm{Y}$ & 98 a $\mathrm{Z}$ & 88 a & $Z$ & 98 a $Z$ & \\
\hline Control 8 WAA $(\%)$ & & & & & & \\
\hline Check & $\begin{array}{lll}0 & \mathrm{c} & \mathrm{X}\end{array}$ & 86 a Z & 53 a & $\mathrm{Y}$ & 87 a $Z$ & \\
\hline Trifluralin & $7 \quad b \quad X$ & 81 a $Y Z$ & 70 a & $\mathrm{Y}$ & 95 a $Z$ & \\
\hline$S$-metolachlor & $10 \mathrm{~b} X$ & 94 a Z & 77 a & $\mathrm{Y}$ & 92 a $Y Z$ & \\
\hline Trifluralin $+S$-metolachlor & 32 a $\mathrm{X}$ & 95 a Z & $75 \mathrm{a}$ & $\mathrm{Y}$ & 95 a $Z$ & \\
\hline
\end{tabular}

Note. BL: broadleaf herbicide; GRASS: grass herbicide; WAA: weeks after herbicide application.

Means followed by a different letter within a column (a-c) or row (X-Z) within each section are significantly different according to a Tukey-Kramer multiple range test at $\mathrm{P}<0.05$.

\subsubsection{Common Lambsquarters}

There was an interaction between "Grass herbicide" and "Broadleaf herbicide" for the common lambsquarters control (4 and 8 WAA), density and biomass so the simple effects are presented (Table 6). At 4 WAA, trifluralin, S-metolachlor and trifluralin + S-metolachlor controlled common lambsquarters $91 \%, 55 \%$ and $95 \%$, respectively (Table 7). Common lambsquarters control was $9 \%$ and $9 \%$ higher when imazethapyr or halosulfuron + imazethapyr were added to trifluralin; $43 \%, 44 \%$ and $45 \%$ higher when halosulfuron, imazethapyr or halosulfuron + imazethapyr were added to S-metolachlor; and 5\%, 5\% and 5\% higher when halosulfuron, imazethapyr or halosulfuron + imazethapyr were added to trifluralin + S-metolachlor, respectively. Halosulfuron, imazethapyr and halosulfuron + imazethapyr controlled common lambsquarters $95 \%, 97 \%$ and $100 \%$, respectively. The control of common lambsquarters was improved 5\% when trifluralin + S-metolachlor was added to halosulfuron. At $8 \mathrm{WAA}$, trifluralin, S-metolachlor and trifluralin + S-metolachlor controlled common lambsquarters $81 \%, 38 \%$ and $91 \%$, respectively (Table 7). Common lambsquarters control was $18 \%$ higher when imazethapyr or halosulfuron + imazethapyr were added to trifluralin; $58 \%, 61 \%$ and $61 \%$ higher when halosulfuron, imazethapyr or halosulfuron + imazethapyr were added to S-metolachlor; and $9 \%$ higher when halosulfuron + imazethapyr was added to trifluralin + S-metolachlor. Halosulfuron, imazethapyr and halosulfuron + imazethapyr controlled common lambsquarters $97 \%, 97 \%$ and $99 \%$, respectively. The control of common lambsquarters was not improved when trifluralin, S-metolachlor or trifluralin + S-metolachlor were added to the aforementioned herbicides. Trifluralin, S-metolachlor and trifluralin + S-metolachlor reduced 
common lambsquarters density $72 \%, 66 \%$ and $78 \%$, respectively. Common lambsquarters density was reduced $84 \%, 94 \%$ and $100 \%$ with tankmixes of trifluralin + halosulfuron, imazethapyr or halosulfuron + imazethapyr; $84 \%, 98 \%$ and $98 \%$ with tankmixes of S-metolachlor + halosulfuron, imazethapyr or halosulfuron + imazethapyr; and $87 \%, 96 \%$ and $97 \%$ with tankmixes of trifluralin + S-metolachlor plus halosulfuron, imazethapyr or halosulfuron + imazethapyr, respectively. Halosulfuron, imazethapyr and halosulfuron + imazethapyr reduced common lambsquarters density $90 \%, 96 \%$ and $98 \%$, respectively. The addition of trifluralin + S-metolachlor to halosulfuron reduced the density from 90 to $96 \%$. Trifluralin, S-metolachlor and trifluralin + S-metolachlor reduced common lambsquarters biomass $91 \%, 66 \%$ and $78 \%$, respectively (Table 7). Common lambsquarters biomass was not reduced when halosulfuron was added to trifluralin but was reduced to $99 \%$ and $100 \%$ when imazethapyr or halosulfuron + imazethapyr were added to trifluralin, respectively. Common lambsquarters biomass was reduced $98 \%, 99 \%$ and $99 \%$ with tankmixes of S-metolachlor + halosulfuron, imazethapyr or halosulfuron + imazethapyr. Common lambsquarters biomass was not reduced when halosulfuron was added to trifluralin + S-metolachlor but was reduced $100 \%$ when imazethapyr or halosulfuron + imazethapyr were added to trifluralin + S-metolachlor. Halosulfuron, imazethapyr and halosulfuron + imazethapyr reduced common lambsquarters biomass $96 \%, 97 \%$ and $98 \%$, respectively. The addition of trifluralin, S-metolachlor or trifluralin + S-metolachlor to the aforementioned herbicides did not reduce the common lambsquarters biomass. In other studies, common lambsquarters was controlled 60-92\% with trifluralin PPI (Li et al., 2016, 2017; Soltani et al., 2012 a-b; Soltani et al., 2010; Soltani et al., 2014a); 19-82\% with S-metolachlor PPI (Li et al., 2016, 2017; Soltani et al., 2014a); 78-100\% with imazethapyr PPI (Li et al., 2017; Soltani et al., 2012a; Soltani et al., 2014a); and $96-100 \%$ with halosulfuron PPI (Li et al., 2016, 2017; Soltani et al., 2014a). The two-way tankmixes of trifluralin + halosulfuron and S-metolachlor + halosulfuron applied PPI were shown to provide $99-100 \%$ control of common lambsquarters in white bean (Soltani et al., 2020).

Table 6. Common lambsquarters control, density and biomass in response to preplant incorporated applications of various combinations of grass and broadleaf herbicides for five factorial trials conducted at Exeter and Ridgetown, ON (2018-2020). Means for a main effect were separated only if the interaction involving the main effect was negligible

\begin{tabular}{|c|c|c|c|c|c|}
\hline \multirow{2}{*}{ Main effects } & & \multicolumn{2}{|c|}{ Control (\%) } & \multirow{2}{*}{ Density (plants $\mathrm{m}^{-2}$ ) } & \multirow{2}{*}{ Biomass $\left(\mathrm{g} \mathrm{m}^{-2}\right)$} \\
\hline & & 4 WAA & 8 WAA & & \\
\hline Grass herbicide & Rate $\left(g a i h a^{-1}\right)$ & & & & \\
\hline Check & 0 & 77 & 76 & 9.3 & 6.3 \\
\hline Trifluralin & 600 & 98 & 96 & 2.1 & 1.7 \\
\hline$S$-metolachlor & 1050 & 93 & 90 & 2.4 & 2.1 \\
\hline Trifluralin $+S$-metolachlor & $600+1050$ & 99 & 98 & 1.5 & 1.0 \\
\hline GRASS P-value & & $<0.0001$ & $<0.0001$ & $<0.0001$ & 0.0001 \\
\hline \multicolumn{6}{|l|}{ Broadleaf herbicide } \\
\hline Check & 0 & 58 & 48 & 18.8 & 12.7 \\
\hline Halosulfuron & 26 & 98 & 96 & 1.9 & 1.7 \\
\hline Imazethapyr & 37.5 & 99 & 99 & 0.6 & 0.4 \\
\hline Halosulfuron + imazethapyr & $26+37.5$ & 100 & 99 & 0.3 & 0.3 \\
\hline BL P-value & & $<0.0001$ & $<0.0001$ & $<0.0001$ & $<0.0001$ \\
\hline \multicolumn{6}{|l|}{ Interaction } \\
\hline GRASS $\times$ BL P-value & & $<0.0001$ & $<0.0001$ & $<0.0001$ & $<0.0001$ \\
\hline
\end{tabular}

Note. BL: broadleaf herbicide; GRASS: grass herbicide; WAA: weeks after herbicide application. 
Table 7. Simple effects for common lamb's-quarters control, density and biomass in response to preplant incorporated applications of various combinations of grass and broadleaf herbicides for five factorial trials conducted at Exeter and Ridgetown, ON (2018-2020)

\begin{tabular}{|c|c|c|c|c|c|c|c|c|c|c|c|c|}
\hline \multirow{3}{*}{$\begin{array}{l}\text { Grass herbicide } \\
\text { Control } 4 \text { WAA (\%) }\end{array}$} & \multicolumn{12}{|c|}{$\begin{array}{l}\text { Broadleaf herbicide } \\
\end{array}$} \\
\hline & \multicolumn{3}{|c|}{ Check } & \multicolumn{3}{|c|}{ Halosulfuron $\left(26 \mathrm{~g}\right.$ ai ha $\left.{ }^{-1}\right)$} & \multicolumn{3}{|c|}{ Imazethapyr (37.5 g ai ha $\left.{ }^{-1}\right)$} & \multicolumn{3}{|c|}{ Halosulfuron + imazethapyr } \\
\hline & & & & & & & & & & & & \\
\hline Check & 0 & $\mathrm{c}$ & $\mathrm{X}$ & 95 & $\mathrm{~b}$ & $\mathrm{Y}$ & 97 & $\mathrm{a}$ & $\mathrm{YZ}$ & 100 & $\mathrm{a}$ & $\mathrm{Z}$ \\
\hline Trifluralin $\left(600 \mathrm{~g}_{\text {ai }} \mathrm{ha}^{-1}\right)$ & 91 & $\mathrm{a}$ & $\mathrm{Y}$ & 97 & $a b$ & $\mathrm{YZ}$ & 100 & $\mathrm{a}$ & $\mathrm{Z}$ & 100 & a & Z \\
\hline$S$-metolachlor (1050 g ai ha $\left.{ }^{-1}\right)$ & 55 & $\mathrm{~b}$ & $\mathrm{Y}$ & 98 & $\mathrm{ab}$ & $\mathrm{Z}$ & 99 & $\mathrm{a}$ & Z & 100 & a & Z \\
\hline Trifluralin $+S$-metolachlor & 95 & $\mathrm{a}$ & Y & 100 & $\mathrm{a}$ & Z & 100 & a & Z & 100 & a & Z \\
\hline \multicolumn{13}{|l|}{ Control 8 WAA (\%) } \\
\hline Check & 0 & $\mathrm{c}$ & $\mathrm{Y}$ & 94 & $\mathrm{a}$ & $\mathrm{Z}$ & 97 & $\mathrm{a}$ & $\mathrm{Z}$ & 99 & $\mathrm{a}$ & $\mathrm{Z}$ \\
\hline Trifluralin (600 $\left.\mathrm{g}_{\text {ai ha }}{ }^{-1}\right)$ & 81 & $\mathrm{a}$ & $\mathrm{Y}$ & 94 & $\mathrm{a}$ & $\mathrm{YZ}$ & 99 & $\mathrm{a}$ & Z & 99 & $\mathrm{a}$ & Z \\
\hline$S$-metolachlor (1050 g ai ha $\left.{ }^{-1}\right)$ & 38 & $\mathrm{~b}$ & $\mathrm{Y}$ & 96 & $\mathrm{a}$ & $\mathrm{Z}$ & 99 & $\mathrm{a}$ & $\mathrm{Z}$ & 99 & $\mathrm{a}$ & Z \\
\hline Trifluralin $+S$-metolachlor & 91 & $\mathrm{a}$ & $\mathrm{Y}$ & 99 & $\mathrm{a}$ & $\mathrm{YZ}$ & 99 & $\mathrm{a}$ & $\mathrm{YZ}$ & 100 & a & Z \\
\hline \multicolumn{13}{|l|}{ Density (plants $\mathrm{m}^{-2}$ ) } \\
\hline Check & 35.7 & $\mathrm{~b}$ & $\mathrm{Z}$ & 3.7 & $\mathrm{~b}$ & $\mathrm{Y}$ & 1.3 & $\mathrm{a}$ & $\mathrm{YZ}$ & 0.7 & $\mathrm{a}$ & $\mathrm{Z}$ \\
\hline Trifluralin $\left(600 \mathrm{~g}\right.$ ai ha $\left.{ }^{-1}\right)$ & 10.3 & $\mathrm{a}$ & $\mathrm{X}$ & 1.6 & $a b$ & $\mathrm{Y}$ & 0.6 & $\mathrm{a}$ & $\mathrm{YZ}$ & 0.0 & $\mathrm{a}$ & Z \\
\hline$S$-metolachlor (1050 g ai ha $\left.{ }^{-1}\right)$ & 12.2 & $\mathrm{a}$ & $\mathrm{Y}$ & 1.9 & $a b$ & $\mathrm{Z}$ & 0.3 & $\mathrm{a}$ & Z & 0.3 & $\mathrm{a}$ & Z \\
\hline Trifluralin $+S$-metolachlor & 7.8 & $\mathrm{a}$ & $\mathrm{Y}$ & 1.0 & $\mathrm{a}$ & Z & 0.3 & $\mathrm{a}$ & Z & 0.2 & $\mathrm{a}$ & Z \\
\hline \multicolumn{13}{|l|}{ Biomass $\left(\mathrm{g} \mathrm{m}^{-2}\right)$} \\
\hline Check & 38.5 & $\mathrm{c}$ & Y & 1.7 & $\mathrm{a}$ & $\mathrm{Z}$ & 1.2 & $\mathrm{a}$ & $\mathrm{Z}$ & 0.7 & $\mathrm{a}$ & $\mathrm{Z}$ \\
\hline Trifluralin $\left(600 \mathrm{~g}\right.$ ai ha $\left.{ }^{-1}\right)$ & 3.3 & $\mathrm{a}$ & $\mathrm{Y}$ & 5.4 & $\mathrm{a}$ & $\mathrm{Y}$ & 0.3 & $\mathrm{a}$ & Z & 0.1 & $\mathrm{a}$ & Z \\
\hline$S$-metolachlor (1050 g ai ha $\left.{ }^{-1}\right)$ & 12.3 & $\mathrm{~b}$ & $\mathrm{Y}$ & 0.6 & $\mathrm{a}$ & Z & 0.3 & $\mathrm{a}$ & Z & 0.5 & $\mathrm{a}$ & Z \\
\hline Trifluralin $+S$-metolachlor & 5.3 & $\mathrm{a}$ & $\mathrm{Y}$ & 0.8 & $\mathrm{a}$ & $\mathrm{YZ}$ & 0.0 & $\mathrm{a}$ & $\mathrm{Z}$ & 0.0 & $\mathrm{a}$ & $\mathrm{Z}$ \\
\hline
\end{tabular}

Note. WAA: weeks after herbicide application.

Means followed by a different letter within a column (a-c) or row (X-Z) within each section are significantly different according to a Tukey-Kramer multiple range test at $\mathrm{P}<0.05$.

\subsubsection{Wild Mustard}

There was as an interaction between "Grass herbicide" and "Broadleaf herbicide" for wild mustard control (4 and 8 WAA) so the simple effects are presented (Table 8). There was no interaction between "Grass herbicide" and "Broadleaf herbicide" for wild mustard density and biomass so the main effects are presented. Trifluralin, S-metolachlor and trifluralin + S-metolachlor controlled wild mustard $16 \%, 32 \%$ and $63 \%$ at 4 WAA and $8 \%, 13 \%$ and $46 \%$ at 8 WAA (Table 8 ). The addition of halosulfuron, imazethapyr or halosulfuron + imazethapyr to the aforementioned herbicides improved will mustard control to $96-100 \%$. Halosulfuron, imazethapyr and halosulfuron + imazethapyr controlled wild mustard $96-100 \%$ and $97-100 \%$ at 4 and 8 WAA, respectively. There was no improvement in wild mustard control when trifluralin, S-metolachlor or trifluralin + S-metolachlor were added to the aforementioned herbicides. Trifluralin, S-metolachlor or trifluralin + S-metolachlor when averaged across "Broadleaf herbicide" did not reduce wild mustard density or biomass. Halosulfuron, imazethapyr or halosulfuron + imazethapyr when averaged across "Grass herbicide" reduced wild mustard density $97-99 \%$ and biomass $98-100 \%$. In other studies, wild mustard was controlled 11-44\% with trifluralin PPI (Li et al., 2016; Soltani et al., 2012a, 2012b; Soltani et al., 2010; Soltani et al., 2014a); 11-55\% with S-metolachlor PPI (Li et al., 2016; Soltani et al., 2014a); 96\% with imazethapyr PPI (Soltani et al., 2014a); and 99-100\% with halosulfuron PPI (Li et al., 2016; Soltani et al., 2014a). The two-way tankmixes of trifluralin + halosulfuron and S-metolachlor + halosulfuron applied PPI were shown to provide $99-100 \%$ control of wild mustard in white bean (Soltani et al., 2020). 
Table 8. Wild mustard control, density and biomass in response to preplant incorporated applications of various combinations of grass and broadleaf herbicides for three factorial trials conducted at Exeter, ON (2018-2020). Means for a main effect were separated only if the interaction involving the main effect was negligible

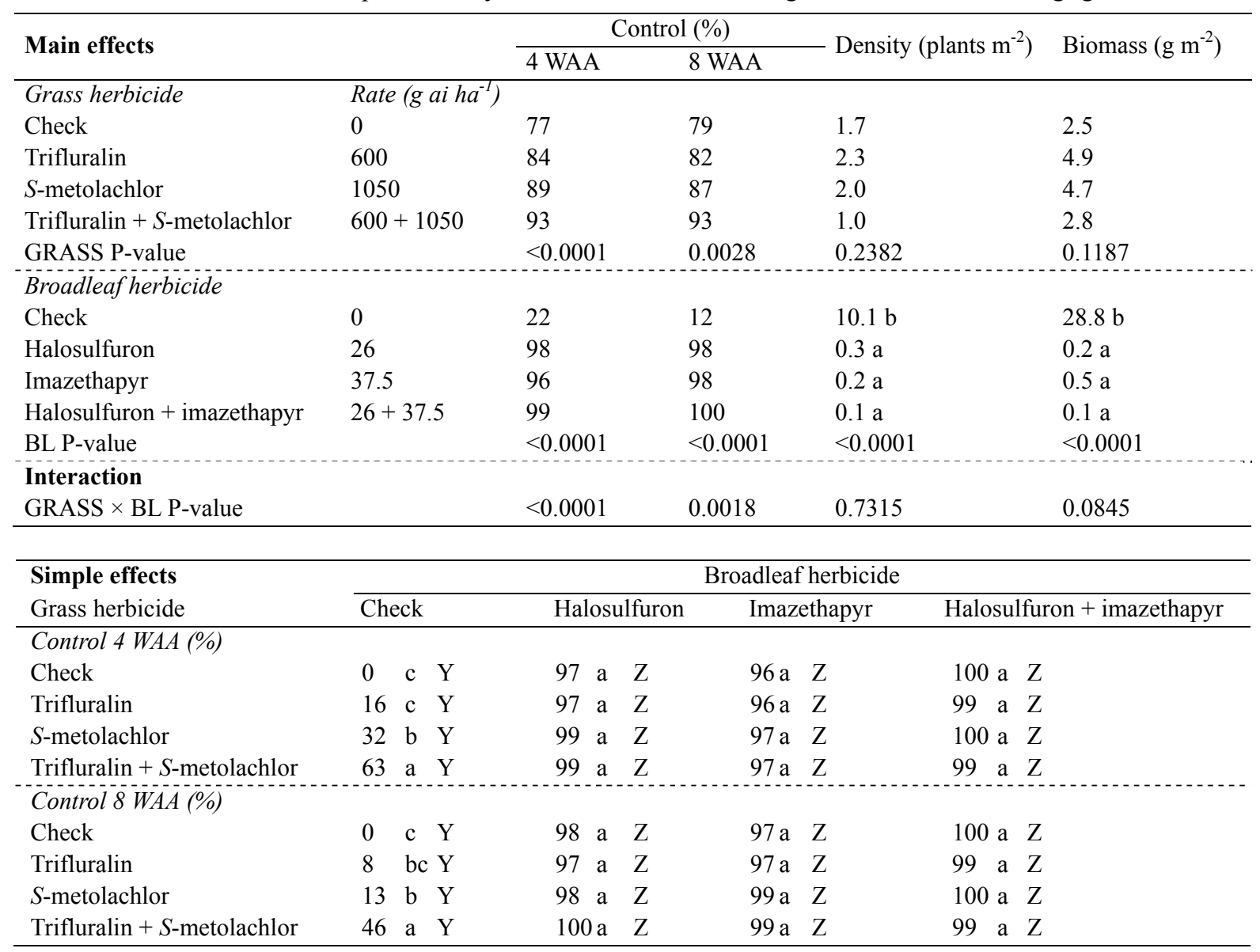

Note. BL: broadleaf herbicide; GRASS: grass herbicide; WAA: weeks after herbicide application.

Means followed by a different letter within a column (a-c) or row (Y-Z) within each section are significantly different according to a Tukey-Kramer multiple range test at $\mathrm{P}<0.05$.

\subsubsection{Barnyardgrass}

There was as an interaction between "Grass herbicide" and "Broadleaf herbicide" for barnyard grass control (4 and 8 WAA) and biomass so the simple effects are presented (Table 9). There was no interaction between "Grass herbicide" and "Broadleaf herbicide" for barnyardgrass density so the main effects is presented. Trifluralin, S-metolachlor and trifluralin + S-metolachlor controlled barnyardgrass $94 \%, 96 \%$ and $97 \%$ at 4 WAA and $70 \%$, $85 \%$ and $94 \%$ at 8 WAA, respectively. The addition of halosulfuron, imazethapyr or halosulfuron + imazethapyr to the aforementioned herbicides did not improve barnyardgrass control. Halosulfuron, imazethapyr and halosulfuron + imazethapyr controlled barnyardgrass $29 \%, 71$ and $87 \%$ at 4 WAA and 8,60 and $59 \%$ at 8 WAA, respectively. The addition of trifluralin, S-metolachlor or trifluralin + S-metolachlor to the aforementioned broadleaf herbicides improved barnyard control to $80-98 \%$. S-metolachlor reduced barnyardgrass biomass $74 \%$. The addition of imazethapyr or halosulfuron + imazethapyr to trifluralin reduced barnyardgrass biomass $85 \%$ and $92 \%$, respectively, and the addition of imazethapyr to trifluralin + S-metolachor reduced barnyardgrass biomass $92 \%$. Trifluralin, S-metolachlor and trifluralin + S-metolachlor when averaged across "Broadleaf herbicide" reduced barnyardgrass density $65 \%, 79 \%$ and $87 \%$, respectively. Halosulfuron, imazethapyr and halosulfuron + imazethapyr when averaged across "Grass herbicide" reduced barnyard grass density $0 \%, 33 \%$ and $37 \%$, respectively. In other studies, barnyard grass was controlled $58 \%$ with trifluralin PPI (Li et al., 2017; Soltani et al., 2012a) and 13-91\% with imazethapyr PPI (Li et al., 2017; Soltani et al., 2012a). The two-way tankmixes of trifluralin + halosulfuron and S-metolachlor + halosulfuron applied PPI were provided 97-99\% control of barnyardgrass in white bean (Soltani et al., 2020). 
Table 9. Barnyard grass control, density and biomass in response to preplant incorporated applications of various combinations of grass and broadleaf herbicides for two factorial trials conducted at Ridgetown, ON (2019-2020). Means for a main effect were separated only if the interaction involving the main effect was negligible

\begin{tabular}{|c|c|c|c|c|c|c|c|c|}
\hline \multirow{2}{*}{ Main effects } & & \multicolumn{4}{|c|}{ Control $(\%)$} & \multirow{2}{*}{\multicolumn{2}{|c|}{ Density (plants $\mathrm{m}^{-2}$ ) }} & \multirow{2}{*}{ Biomass $\left(\mathrm{g} \mathrm{m}^{-2}\right)$} \\
\hline & & \multicolumn{2}{|c|}{4 WAA } & \multicolumn{2}{|l|}{8 WAA } & & & \\
\hline Grass herbicide & Rate (g ai ha $\left.a^{-1}\right)$ & & & & & & & \\
\hline Check & 0 & 41 & \multicolumn{2}{|r|}{22} & & \multicolumn{2}{|l|}{$19.4 \mathrm{c}$} & 76.8 \\
\hline Trifluralin & 600 & 95 & \multicolumn{2}{|r|}{87} & & \multicolumn{2}{|l|}{$6.7 \mathrm{~b}$} & 27.2 \\
\hline$S$-metolachlor & 1050 & 97 & \multicolumn{2}{|r|}{90} & & \multicolumn{2}{|l|}{$4.1 \mathrm{ab}$} & 9.5 \\
\hline Trifluralin $+S$-metolachlor & \multirow[t]{2}{*}{$600+1050$} & 97 & \multicolumn{2}{|r|}{95} & & \multicolumn{2}{|l|}{$2.6 \mathrm{a}$} & 8.3 \\
\hline GRASS P-value & & \multicolumn{2}{|l|}{$<0.0001$} & $<0.0001$ & & \multicolumn{2}{|l|}{$<0.0001$} & $<0.0001$ \\
\hline \multicolumn{9}{|l|}{ Broadleaf herbicide } \\
\hline Check & 0 & 73 & & 59 & & $8.9 \mathrm{ab}$ & & 36.9 \\
\hline Halosulfuron & 26 & 84 & & 70 & & $12.6 \mathrm{~b}$ & & 51.6 \\
\hline Imazethapyr & 37.5 & 94 & & 87 & & $6.0 \mathrm{ab}$ & & 18.5 \\
\hline Halosulfuron + imazethapyr & $26+37.5$ & 96 & & 89 & & $5.6 \mathrm{a}$ & & 19.5 \\
\hline BL P-value & & $<0.0001$ & & 0.0001 & & 0.0084 & & 0.0027 \\
\hline Interaction & & & & & & & & \\
\hline GRASS $\times$ BL P-value & & $<0.0001$ & & 0.0146 & & 0.2743 & & 0.0258 \\
\hline Simple effects & & & & Broad & lleaf $\mathrm{h}$ & herbicide & & \\
\hline Grass herbicide & Check & Halos & ulfuror & & mazet & thapyr & Halosulfur & on + imazethapyr \\
\hline Control 4 WAA (\%) & & & & & & & & \\
\hline Check & $\begin{array}{lll}0 & \mathrm{~b} & \mathrm{~W}\end{array}$ & $29 \mathrm{~b}$ & $\mathrm{X}$ & & $7 \mathrm{~b}$ & $\mathrm{Y}$ & $87 \mathrm{~b} \quad \mathrm{Z}$ & \\
\hline Trifluralin & $94 \mathrm{a}$ & $92 \mathrm{a}$ & & & $7 \mathrm{a}$ & & $97 \mathrm{a}$ & \\
\hline$S$-metolachlor & 96 a & $97 \mathrm{a}$ & & 9 & $7 \mathrm{a}$ & & 97 a & \\
\hline Trifluralin $+S$-metolachlor & $97 \mathrm{a}$ & $97 \mathrm{a}$ & & & $8 \mathrm{a}$ & & $98 \mathrm{a}$ & \\
\hline Control 8 WAA $(\%)$ & & & & & & & & \\
\hline Check & $\begin{array}{lll}0 & \mathrm{~b} & \mathrm{Y}\end{array}$ & $8 \mathrm{~b}$ & $\mathrm{Y}$ & & $0 \mathrm{~b}$ & $\mathrm{Z}$ & $59 \mathrm{~b}$ & \\
\hline Trifluralin & $70 \mathrm{a}$ & $80 \mathrm{a}$ & & & $5 \mathrm{a}$ & & $95 \mathrm{a}$ & \\
\hline$S$-metolachlor & $85 \mathrm{a}$ & $90 \mathrm{a}$ & & & $2 \mathrm{a}$ & & $93 \mathrm{a}$ & \\
\hline Trifluralin $+S$-metolachlor & $94 \mathrm{a}$ & $94 \mathrm{a}$ & & & $7 \mathrm{a}$ & & 96 a & \\
\hline Biomass $\left(\mathrm{g} \mathrm{m}^{-2}\right)$ & & & & & & & & \\
\hline Check & $39 \mathrm{~b}$ & $103 \mathrm{~b}$ & & & $1 \mathrm{~b}$ & & $84 \mathrm{~b}$ & \\
\hline Trifluralin & $33 \mathrm{ab} \mathrm{Y}$ & $44 \mathrm{~b}$ & $\mathrm{Y}$ & 6 & a & $\mathrm{Z}$ & 3 a $Z$ & \\
\hline$S$-metolachlor & $10 \mathrm{a}$ & $9 \mathrm{a}$ & & 9 & $\mathrm{a}$ & & $4 \mathrm{a}$ & \\
\hline Trifluralin $+S$-metolachlor & $15 \mathrm{ab} \mathrm{Y}$ & 8 & $\mathrm{YZ}$ & 3 & $\mathrm{a}$ & $\mathrm{Z}$ & 5 a $\mathrm{YZ}$ & \\
\hline
\end{tabular}

Note. BL: broadleaf herbicide; GRASS: grass herbicide; WAA: weeks after herbicide application.

Means followed by a different letter within a column (a-c) or row (W-Z) within each section are significantly different according to a Tukey-Kramer multiple range test at $\mathrm{P}<0.05$. Rows without an uppercase letter have no difference between the check and broadleaf treatment.

\subsubsection{Green Foxtail}

There was as an interaction between "Grass herbicide" and "Broadleaf herbicide" for green foxtail control (4 and 8 WAA) so the simple effects are presented (Table 10). There was no interaction between "Grass herbicide" and "Broadleaf herbicide" for green foxtail density and biomass so the main effects is presented. Trifluralin, S-metolachlor and trifluralin + S-metolachlor controlled green foxtail $95-98 \%$ at 4 WAA and $89-98 \%$ at 8 WAA, respectively. There was no improvement in green foxtail control when halosulfuron, imazethapyr and halosulfuron + imazethapyr were added to the aforementioned herbicides. Halosulfuron, imazethapyr and halosulfuron + imazethapyr controlled green foxtail $27 \%, 73 \%$ and $78 \%$ at 4 WAA and $19 \%, 69 \%$ and $67 \%$ at 8 WAA, respectively. The addition of trifluralin, S-metolachlor or trifluralin + S-metolachlor to the aforementioned herbicides improved green foxtail control to $88-99 \%$. Trifluralin, S-metolachlor and trifluralin + S-metolachlor when averaged across "Broadleaf herbicide" reduced green foxtail density 83\%, 83\% and 94\% and biomass 79\%, $74 \%$ and $85 \%$, respectively. Halosulfuron and halosulfuron + imazethapyr did not reduce green foxtail density or biomass; imazethapyr reduced green foxtail density and biomass $52 \%$ and $25 \%$, respectively. In other studies, 
green foxtail was controlled 94-100\% with trifluralin PPI (Li et al., 2016, 2017; Soltani et al., 2012a, 2012b; Soltani et al., 2010; Soltani et al., 2014a); 93-97\% with S-metolachlor PPI (Li et al., 2016, 2017; Soltani et al. 2014a); 13-91\% with imazethapyr PPI (Li et al., 2017; Soltani et al., 2012a); and 47-59\% with halosulfuron PPI (Li et al., 2016, 2017; Soltani et al., 2014a). The two-way tankmixes of trifluralin + halosulfuron and S-metolachlor + halosulfuron applied PPI were shown to provide up to $95 \%$ control of green foxtail in white bean (Soltani et al., 2020).

Table 10. Green foxtail control, density and biomass in response to preplant incorporated applications of various combinations of grass and broadleaf herbicides for five factorial trials conducted at Exeter and Ridgetown, ON (2018-2020). Means for a main effect were separated only if the interaction involving the main effect was negligible

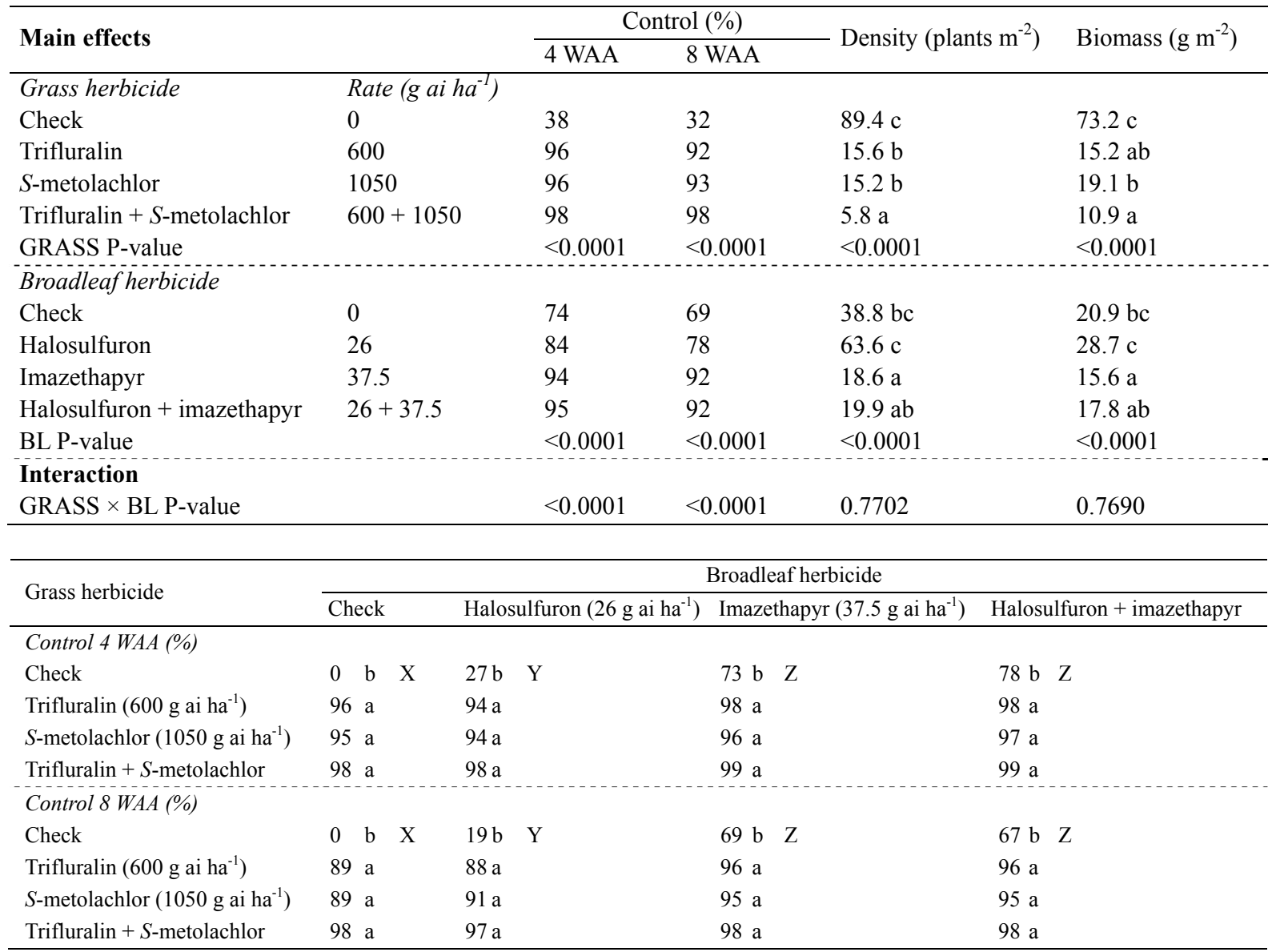

Note. BL: broadleaf herbicide; GRASS: grass herbicide; WAA: weeks after herbicide application.

Means followed by a different letter within a column (a-c) or row (X-Z) within each section are significantly different according to a Tukey-Kramer multiple range test at $\mathrm{P}<0.05$. Rows without an uppercase letter have no difference between the check and broadleaf treatment.

This research concludes that the two- and three-way tankmixes of trifluralin, S-metolachlor, halosulfuron and imazethapyr have adequate margin of crop safety for use in white bean but the four-way tankmix of trifluralin, S-metolachlor, halosulfuron and imazethapyr has the potential to cause unacceptable (from the grower's perspective) injury in white bean. Weed interference reduced white bean yield up to 76\%. Generally, the twoand three-way tankmixes of herbicides evaluated provided similar white bean seed yield as the four-way tankmix evaluated. The three- and four-way tankmixes of trifluralin, S-metolachlor, halosulfuron and imazethapyr generally provided the most consistent control of velvetleaf, pigweeds (green and redroot combined), common ragweed, common lambsquarters, wild mustard, barnyardgrass and green foxtail in white bean. Based on these results, depending on the weed species present in the field, the two- or three-way tankmixes of trifluralin, S-metolachlor, halosulfuron and imazethapyr can be used for broad-spectrum weed control in white bean under 
Ontario environmental conditions. Weed management programs that involve tankmixing of herbicides with different modes of action can help reduce the evolution of herbicide-resistant biotypes.

\section{References}

Brown, D., \& Masiunas, J. (2002). Evaluation of Herbicides for Pumpkin (Cucurbita spp.). Weed Technol., 16, 282-292.

Duggleby, R. G., McCourt, J. A., \& Guddat, L. W. (2008). Structure and mechanism of inhibition of plant acetohydroxyacid synthase. Plant Physiol. Biochem., 46, 309-324.

Flessner, M. L., Burke, I. C., Dille, J. A., Everman, W. J., VanGessel, M. J., Tidemann, B., ... Sikkema, P. H. (2021). Potential wheat yield loss due to weeds in the United States and Canada. Weed Technol., in press.

Li, Z., Van Acker, R., Robinson, D. E., Soltani, N., \& Sikkema, P. H. (2016). Halosulfuron tankmixes applied preplant incorporated for weed control in white bean (Phaseolus vulgaris L.). Can. J. Plant Sci. 96, 81-88.

Li, Z., Van Acker, R., Robinson, D. E., Soltani, N., \& Sikkema, P. H. (2017). Managing weeds with herbicides in white bean in Canada: a review Can. J. Plant Sci. 97(5), 755-766.

OBG (Ontario Bean Growers). (2021). Type of beans. Ontario Bean Growers. Available online. https://ontariobeans.on.ca/types-of-beans/

OMAFRA (Ontario Ministry of Agriculture and Food and Rural Affairs). (2020). Guide to weed control, Publication 75. Toronto, ON. pp. 1- 457.

OMAFRA (Ontario Ministry of Agriculture and Food and Rural Affairs). (2021). Area, Yield, Production and Farm Value of Specified Field Crops, Ontario, 2012-2021.

Shaner, D. L. (2014). Herbicide Handbook, Tenth Edition. Champaign, IL: Weed Sci. Soc. Am., 513 pp.

Soltani, N., Nurse, R. E., Van Eerd, L. L., Shropshire, C., \& Sikkema, P. H. (2010). Weed control, environmental impact and profitability with trifluralin plus reduced doses of imazethapyr in dry bean. Crop Prot. 29,364-368.

Soltani, N., Nurse, R. E., \& Sikkema, P. H. (2012a). Weed control in dry bean with pendimethalin plus reduced rates of imazethapyr. Int. Res. J. Agric. Sci. Soil Sci. 2, 312-317.

Soltani, N., Nurse, R. E., Shropshire, C., \& Sikkema, P. H. (2012b). Weed control, environmental impact and profitability of pre-plant incorporated herbicides in white bean. Amer. J. Plant Sci. 3, 846-853.

Soltani, N., Nurse, R. E., Shropshire, C., \& Sikkema, P. H. (2014a). Weed control in white bean with various halosulfuron tankmixes. Adv. Agric. 2014, 1-7.

Soltani, N., Nurse, R. E., Shropshire, C., \& Sikkema, P. H. (2014b). Weed control with halosulfuron applied preplant incorporated, preemergence or postemergence in white bean. Agric. Sci. 5, 875-881.

Soltani, N., Dille, J. A., Burke, I. C., Everman, W. J., VanGessel, M. J., Davis, V. M., \& Sikkema, P. H. (2016). Potential corn yield losses from weeds in North America. Weed Technol., 30, 979-984.

Soltani, N., Dille, J. A., Burke, I. C., Everman, W. J., VanGessel, M. J., Davis, V. M., \& Sikkema, P. H. (2017) Perspectives on potential soybean yield losses from weeds in North America. Weed Technol., 31, 148-15.

Soltani, N., Dille, J. A., Burke, I. C., Everman, W. J., VanGessel, M. J., Davis, V. M., \& Sikkema, P. H. (2018). Potential yield loss in dry bean crops due to weeds in the United States and Canada. Weed Technol., 32, 342-346.

Soltani, N., Shropshire, C., \& Sikkema, P. (2020). Weed Management in White Beans with Soil-Applied Grass Herbicides plus Halosulfuron. Amer. J. Plant Sci., 11, 1998-2011.

\section{Copyrights}

Copyright for this article is retained by the author(s), with first publication rights granted to the journal.

This is an open-access article distributed under the terms and conditions of the Creative Commons Attribution license (http://creativecommons.org/licenses/by/4.0/). 